\title{
OCCUPATIONAL EXPOSURE TO SELECTED ISOCYANATES IN POLISH INDUSTRY
}

\author{
ZAWODOWE NARAŻENIE NA WYBRANE IZOCYJANIANY W POLSKIM PRZEMYŚLE
}

Nofer Institute of Occupational Medicine / Instytut Medycyny Pracy im. prof. J. Nofera, Łódź, Poland Department of Chemical Safety / Zakład Bezpieczeństwa Chemicznego

\begin{abstract}
Background: Isocyanates constitute a group of highly reactive, low molecular weight chemicals used worldwide for polyurethane manufacturing. The occupational exposure to these compounds is a major cause of occupational asthma, thus it is very important to monitor their concentration in the workplace atmosphere. The aim of the study was to measure the concentration of 4,4'-methylenediphenyl diisocyanate (MDI; CAS 101-68-8), toluene-2,4-di-isocyanate (2,4-TDI; CAS 584-84-9), toluene-2,6-di-isocyanate (2,6-TDI; CAS 91-08-7) and hexamethylene di-isocyanate (HDI; CAS 822-06-0) in the work environment for evaluation of the occupational exposure to these compounds. Material and Methods: Determination of concentrations of selected isocyanates was carried out in 21 manufacturing plants, during different industrial processes. The collected air samples (personal samples) were analyzed by means of the high-performance liquid chromatography (HPLC). Results: The presented results represent the 1st data on the occupational exposure to isocyanates in Poland. This set of data is generally indicative of concentrations of analyzed isocyanates that are low and do not exceed the maximum admissible concentration (MAC) values in Poland. Elevated concentrations (above the MAC value) were found only for the TDI in the course of manufacturing of polyurethane foam blocks. Conclusions: Results of many studies show that low concentrations of isocyanates (particularly of low volatility like for example MDI) in the air cannot exclude the possibility of additional absorption of these compounds through skin. Taking into consideration all the uncertainties associated with the evaluation of the risk of exposure to isocyanates based solely on measurement of their levels in the air, it would seem that the simultaneous application of environmental and biological monitoring would only facilitate a reliable assessment of the occupational exposure risk. Med Pr 2015;66(3):291-301
\end{abstract}

Key words: isocyanates, occupational exposure, polyurethanes, 4,4'-methylenediphenyl diisocyanate, toluene diisocyanate, hexamethylene diisocyanate

\section{STRESZCZENIE}

Wstęp: Izocyjaniany stanowią grupę małocząsteczkowych silnie reaktywnych związków chemicznych szeroko stosowanych do produkcji tworzyw poliuretanowych. Uważa się, że zawodowe narażenie na te związki to jeden z głównych czynników powstawania astmy zawodowej i z tego względu istotne jest stałe monitorowanie ich stężeń w środowisku pracy. Celem pracy było wykonanie pomiarów stężeń metylenobis(fenyloizocyjanianu) (MDI; CAS 101-68-8), diizocyjanianu tolueno2,4-diylu (2,4-TDI; CAS 584-84-9), diizocyjanianu tolueno-2,6-diylu (2,6-TDI; CAS 91-08-7), diizocyjanianuheksano-1,6-diylu (HDI; CAS 822-06-0) w środowisku pracy jako podstawy do oceny zawodowego narażenia na te związki. Materiał i metody: Oznaczenia stężeń wybranych izocyjanianów zostały przeprowadzone w 21 zakładach pracy podczas różnych procesów produkcyjnych. Pobrane próbki powietrza analizowano z zastosowaniem wysokosprawnej chromatografii cieczowej (high-performance liquid chromatography - HPLC). Wyniki: Przedstawione wyniki są pierwszymi w Polsce ilościowymi danymi dotyczącymi zawodowego narażenia na izocyjaniany. Wynika z nich, że generalnie stężenia oznaczanych związków pozostają na niskim poziomie i nie przekraczają ustanowionych wartości najwyższego dopuszczalnego stężenia (NDS). Przekroczenia wartości normatywnych stwierdzono jedynie w przypadku TDI podczas produkcji bloków pianki poliuretanowej. Wnioski: Wyniki wielu badań wskazują, że w przypadku niskich stężeń izocyjanianów w powietrzu (szczególnie słabo lotnego MDI) nie można wykluczyć możliwości wchłaniania tych związków przez skórę. Biorąc pod uwagę wszystkie niepewności związane z oceną zawodowego narażenia na izocyjaniany dokonywaną wyłącznie w oparciu o pomiary ich stężeń w powietrzu wydaje się, że jedynie jednoczesne stosowanie monitoringu środowiskowego i monitoringu biologicznego mogłoby pozwolić na wiarygodną ocenę narażenia zawodowego. Med. Pr. 2015;66(3):291-301

Słowa kluczowe: izocyjaniany, narażenie zawodowe, poliuretany, 4,4'-metylenobis(fenyloizocyjanian), toluilenodiizocyjanian, diizocyjanian heksano-1,6-diylu

Corresponding author / Autor do korespondencji: Sławomir Brzeźnicki, Nofer Institute of Occupational Medicine, Department of Chemical Safety, św. Teresy 8, 91-348 Łódź, Poland, e-mail: slawek@imp.lodz.pl Received: May 28, 2014, accepted: October 29, 2014

Funding / Finansowanie: within the project IMP 4.8 titled "Evaluation of reliability of selected isocyanates determinations in the air of workplace based on the biological monitoring of their metabolites eliminated with urine." Project coordinator: Sławomir Brzeźnicki, Ph.D. 


\section{INTRODUCTION}

Isocyanates constitute a group of highly reactive, low molecular weight chemicals used worldwide for manufacturing of polyurethane foam or as components of paints, lacquers or glues. Polyurethanes are applied in many sectors of the economy, and primarily in the construction sector, foundries, footwear, automobile, aeronautical, and shipbuilding industries, and as insulating material for manufacturing of household appliances.

The harmful effect of isocyanates involves irritation of mucous membranes and skin. The most common symptoms of the harmful effects of isocyanates include cough, rhinitis, irritation of eyes, throat, and allergic reactions on the skin.

Isocyanates are recognized as one of the most frequent causes of occupational asthma. It is believed that the occupational exposure to these compounds may be accountable for up to $20 \%$ of all confirmed cases of occupational asthma [1]. Clinical symptoms may develop after a few months and even after a few years following the exposure. In many cases, the symptoms of asthma do not disappear after the exposure is interrupted. Asthma and allergic diseases are not the only harmful results of the exposure to isocyanates. The International Agency for Research on Cancer (IARC), based on animal studies, has included TDI isomers in the group $2 \mathrm{~B}$, i.e., the group of compounds that are possibly carcinogenic to humans [2].

Results of toxicity studies and the increasing number of workers occupationally exposed to this group of compounds have led to significant changes in the maximum admissible concentrations (MAC) in Poland (Table 1) [3].
At present, evaluation of the occupational exposure to isocyanates is based on environmental or biological monitoring of the exposed workers. This is associated with the existence of normative values based on health criteria (admissible concentrations in the air) [3,4] or concentrations of metabolites of these compounds in urine [5]. The 'non-measurement' method for estimating the concentration of harmful substances in the workplace, developed for the purpose of the REACH (Registration, Evaluation and Authorization and restriction of Chemicals) framework regulations [6] is another way to assess the exposure to chemicals. It is based on mathematical models using different exposure scenarios, and the physicochemical data on chemical substances [7-10]. The use of such models had also been attempted for isocyanates [11]. However, it seems that, despite the encouraging results, at the present moment the non-measurement method of assessing the occupational exposure is not suitable yet to replace the methods based on the measurements performed at the workplace.

\section{Aims of the study}

The aim of the study was to assay the concentration of 4,4'-methylenediphenyl diisocyanate (MDI; CAS 10168-8), toluene-2,4-di-isocyanate (2,4-TDI;CAS584-84-9), toluene-2,6-di-isocyanate (2,6-TDI; CAS 91-08-7) and hexamethylene-di-isocyanate (HDI; CAS 822-06-0) in the work environment during various manufacturing processes and, from the resultant data, to evaluate the occupational exposure to isocyanates.

\section{Study design}

The study spans over the years 2002-2012. Determinations of concentrations of the selected isocyanates were

Table 1. Threshold Limit Values (TLV) for isocyanates in Poland in 2002 and 2009

Tabela 1. Wartość normatywów higienicznych dla izocyjanianów w Polsce w latach 2002 i 2009

\begin{tabular}{|c|c|c|c|c|c|c|}
\hline \multirow[t]{2}{*}{$\begin{array}{l}\text { Compound } \\
\text { Związek }\end{array}$} & \multicolumn{2}{|c|}{$\begin{array}{c}\text { MAC } \\
\text { NDS } \\
{\left[\mathrm{mg} / \mathrm{m}^{3}\right]}\end{array}$} & \multicolumn{2}{|c|}{$\begin{array}{c}\text { STEL } \\
\text { NDSCh } \\
{\left[\mathrm{mg} / \mathrm{m}^{3}\right]}\end{array}$} & \multicolumn{2}{|c|}{$\begin{array}{c}\text { Ceiling } \\
\text { NDSP } \\
{\left[\mathrm{mg} / \mathrm{m}^{3}\right]}\end{array}$} \\
\hline & 2002 & 2009 & 2002 & 2009 & 2002 & $2009^{*}$ \\
\hline MDI & 0.050 & 0.030 & & 0.090 & 0.20 & \\
\hline 2,4-TDI & 0.035 & 0.007 & 0.07 & 0.021 & & \\
\hline 2,6-TDI & 0.035 & 0.007 & 0.07 & 0.021 & & - \\
\hline HDI & 0.050 & 0.040 & 0.15 & 0.080 & & \\
\hline
\end{tabular}

MAC - maximum admissible concentration / NDS - najwyższe dopuszczalne stężenie, STEL - short term exposure limit / NDSCh - najwyższe dopuszczalne stężenie chwilowe, Ceiling / NDSP - najwyższe dopuszczalne stężenie pułapowe.

MDI - 4,4'-methylenediphenyl diisocyanate / metylenobis(fenyloizocyjanian), 2,4-TDI - toluene-2,4-di-isocyanate / diizocyjanian tolueno-2,4-diylu, 2,6-TDI - toluene-2,6di-isocyanate / diizocyjanian tolueno-2,6-diylu, HDI - hexamethylene di-isocyanate / diizocyjanian heksano-1,6-diylu.

* Not established / Nie ustanowiono. 
performed under contracts with industry or as a part of study projects conducted by the Nofer Institute of Occupational Medicine (NIOM), Łódź, Poland. Surveys were done in 21 factories located in Poland. Breath- ing zone air samples were collected from 129 of workers exposed to diisocyanates during different types of industrial processes. Manufacturing data in specified workplaces has been compiled in the Table 2 .

Table 2. Types of production output and activities of workers participating to the study

Tabela 2. Rodzaj produkcji i czynności wykonywanych przez pracowników uczestniczących w badaniu

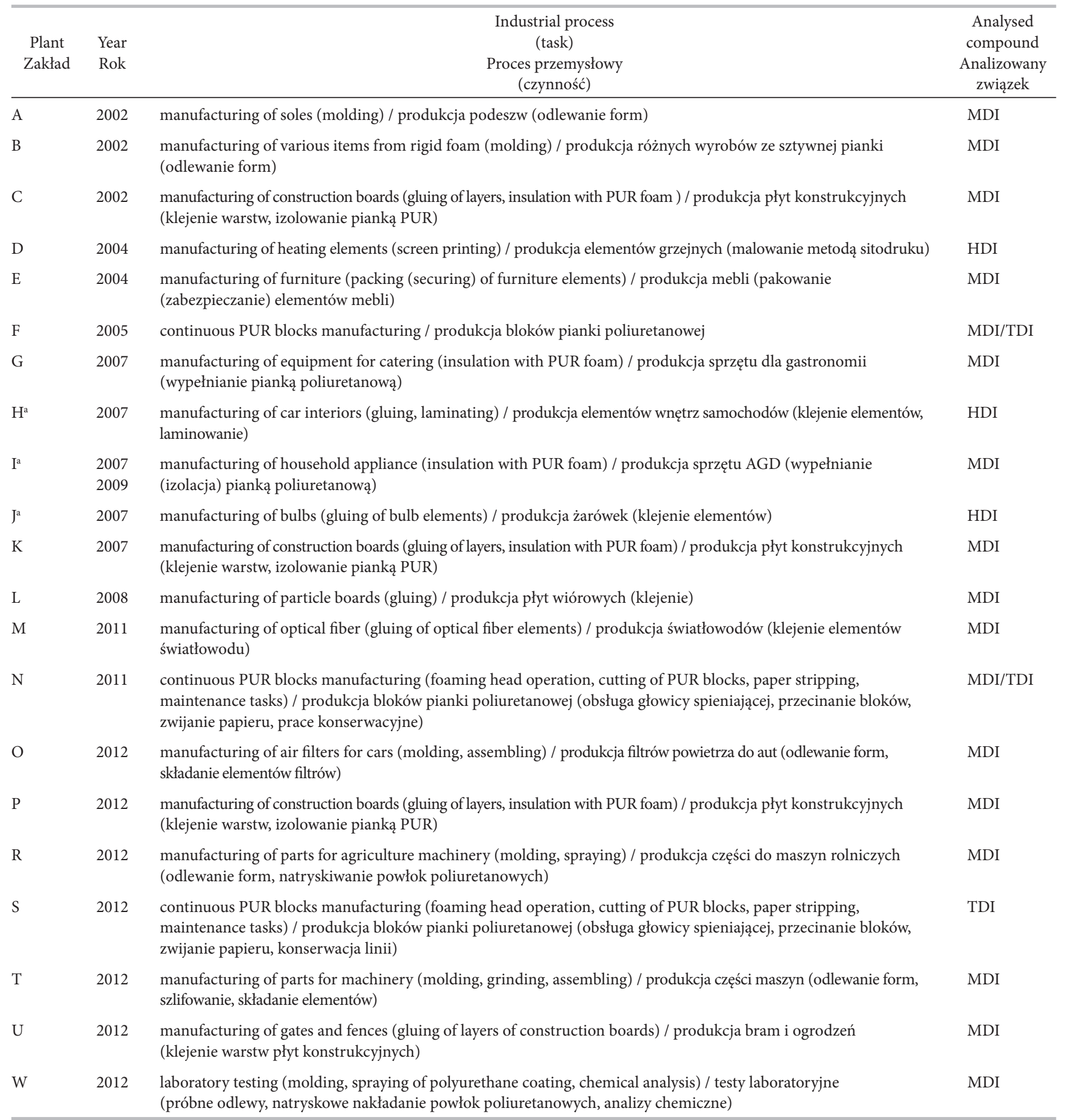

a Plants surveyed twice / Zakłady objęte badaniami 2-krotnie.

PUR - polyurethan / poliuretan, MDI - 4,4'-methylenediphenyl diisocyanate / metylenobis(fenyloizocyjanian), TDI - mixture of 2,4-TDI and 2,6-TDI isomers / mieszanina izomerów 2,4-TDI i 2,6-TDI. 


\section{MATERIAL AND METHODS}

The analytical method used for determination of diisocyanate concentrations was based on the Occupational Safety and Health Administration (OSHA) $[12,13]$ and the Health and Safety Executive (HSE) [14] methodologies. The applied methodology was fully validated and accredited by the Polish Centre for Accreditation.

\section{Chemicals}

Acetonitrile (ACN) was purchased from JT BAKER, (Deventer, Holland), 1-(2-pyridyl)piperazine (1,2-PP) from Sigma-Aldrich (USA St Louis), ammonium acetate and dimethyl sulphoxide (DMSO) were purchased from Avantor Performance Materials Poland (Polskie Odczynniki Chemiczne - POCh, Gliwice, Poland). During the period from 2001 to 2009, standards of 2,4-TDI, 2,6-TDI, HDI and MDI derivatives were prepared according to the OSHA 42 and OSHA 47 methods. After 2010, standards of isocyanate derivatives were purchased from AccuStandard (New Haven, USA).

\section{Collection of air samples}

Prior to collection of air samples, glass fiber filters (Whatman GF/A) were coated with the $2 \mathrm{mg} / \mathrm{ml}$ solution of 1,2-PP in acetonitrile. Air samples (200 1, 1 1/min) were collected in the breathing zone of workers using GliAir-3 (Gillian) individual aspirators. Filters with collected air samples were placed in air-tight containers, and stored at $4^{\circ} \mathrm{C}$ until the analysis.

\section{Analytical procedure}

Filters were extracted with mixture $(2 \mathrm{ml})$ of ACN:DMSO (9:1 v:v) in a rotary shaker (1 h). Extracts were transferred via syringe polytetrafluoroethylene (PTFE) filters (Supelco) to the autosampler vial and analyzed using the Waters Alliance 2695 highperformance liquid chromatography (HPLC) system equipped with the Waters 2475 fluorescence detector (FLD) and the Waters 2996 photodiode array detector (PAD). Calibration standards were prepared on 1,2-PP coated filters spiked with consecutive dilutions of 2,4-TDI, 2,6-TDI, HDI and MDI derivative mixtures. After evaporation of solvent, filters were treated in the same way as the sample filters.

Chromatographic separations were performed on Sulelcosil LC-CN (2002-2011) or Ascentis RP-Amide (2012) (Supelco) columns. Chromatographic conditions and validation parameters of the analytical method are specified in the Tables 3 and 4. Chromatograms of standards of 2,4-TDI, HDI, 2,6-TDI, MDI derivatives and one of the analyzed air samples are shown on the Figure 1.

Table 3. HPLC conditions for determination of selected diisocyanates Tabela 3. Warunki oznaczania wybranych izocyjanianów techniką HPLC

\begin{tabular}{lcc}
\hline \multicolumn{1}{c}{$\begin{array}{c}\text { Parameter } \\
\text { Parametr }\end{array}$} & $\begin{array}{c}\text { Analytical conditions } \\
\text { Warunki analityczne }\end{array}$ & $\begin{array}{c}\text { Ascentis RP Amide, } \\
150 \times 2.1,5 \mathrm{~mm}\end{array}$ \\
\hline Analytical column / Kolumna analityczna & $\begin{array}{c}\text { Supelcosil LC-CN, } \\
250 \times 3 \mathrm{~mm}, 5 \mathrm{~mm}\end{array}$ & ACN:AA \\
Mobile phase / Faza ruchoma & ACN:AA & $0(10: 90)$ \\
Gradient / Gradient [min (ACN:AA)] & $0(0: 100)$ & $6(50: 50)$ \\
& $22(55: 45)$ & $15(50: 50)$ \\
& $25(0: 100)$ & $16(10: 90)$ \\
& $35(0: 100)$ & $26(10: 90)$ \\
Column temperature / Temperatura kolumny & - & $35^{\circ} \mathrm{C}$ \\
Flow rate / Strumień objętości & $35^{\circ} \mathrm{C}$ & $0.5 \mathrm{ml} / \mathrm{min}$ \\
Sample volume / Objętość próbki & $0.4 \mathrm{ml} / \mathrm{min}$ & $10 \mu l$ \\
FLD $\lambda$ ex $/ \lambda_{\text {em }}$ & $10 \mathrm{ml}$ & $260 / 370 \mathrm{~nm}$ \\
PAD scan (range) / Skan (zakres) & $260 / 370 \mathrm{~nm}$ & $200-400 \mathrm{~nm}$
\end{tabular}

HPLC - high-performance liquid chromatography / wysokosprawna chromatografia cieczowa, ACN - acetonitrile / acetonitryl, AA - ammonium acetate buffer (0.01 M, $\mathrm{pH}=5.5) /$ bufor octanowy $(0,01 \mathrm{~mol} / \mathrm{l}, \mathrm{pH}=5,5), \mathrm{FLD}$ - fluorescence detector / detektor fluorescencyjny, PAD - photodiode array detector / detektor diodowy.

$\lambda_{\mathrm{ex}}$ - excitation wavelengths / długość fali wzbudzenia, $\lambda_{\mathrm{em}}$ - emission wavelengths / długość fali emisji. 
Table 4. Validation parameters of the analytical method applied

Tabela 4. Dane walidacyjne stosowanej metody analitycznej

\begin{tabular}{|c|c|c|c|c|}
\hline $\begin{array}{l}\text { Parameter } \\
\text { Parametr }\end{array}$ & 2,4-TDI & 2,6-TDI & HDI & MDI \\
\hline Range / Zakres $[\mu \mathrm{g} / 2 \mathrm{ml}]$ & $0.028-2.80$ & $0.028-2.80$ & $0.16-16$ & $0.12-12$ \\
\hline Regression coefficient / Współczynnik regresji (r) & 0.999 & 0.999 & 0.999 & 0.999 \\
\hline Relative standard deviation / Względne odchylenie standardowe [\%] & 5.60 & 5.70 & 2.20 & 4.70 \\
\hline $\begin{array}{l}\text { Average* retention efficiency (200 } 1 \text { air sample, flow rate } 1 \text { 1/min) / Średnia } \\
\text { wartość retencji ( } 2001 \text { powietrza, strumień o objętości } 1 \text { 1/min) [\%] }\end{array}$ & 92.80 & 93.20 & 105.30 & 101.20 \\
\hline $\begin{array}{l}\text { Average* recovery after storage (30 days, refrigerator) / Średnia wartość } \\
\text { współczynnika odzysku (30 dni w chłodziarce) [\%] }\end{array}$ & 91.50 & 90.50 & 95.60 & 98.10 \\
\hline
\end{tabular}

* Arithmetic mean from replicate $(\mathrm{N}=6)$ determinations of analytical standards at concentrations equal 1/50,1/10 and $1 / 2$ of the MAC value / Średnia arytmetyczna z powtórzeń $(\mathrm{N}=6)$ analiz wzorców o stężeniach równych 1/50, 1/10 i 1/2 wartości NDS.

Abbreviations as in the Table 1 / Skróty jak w tabeli 1.

a)

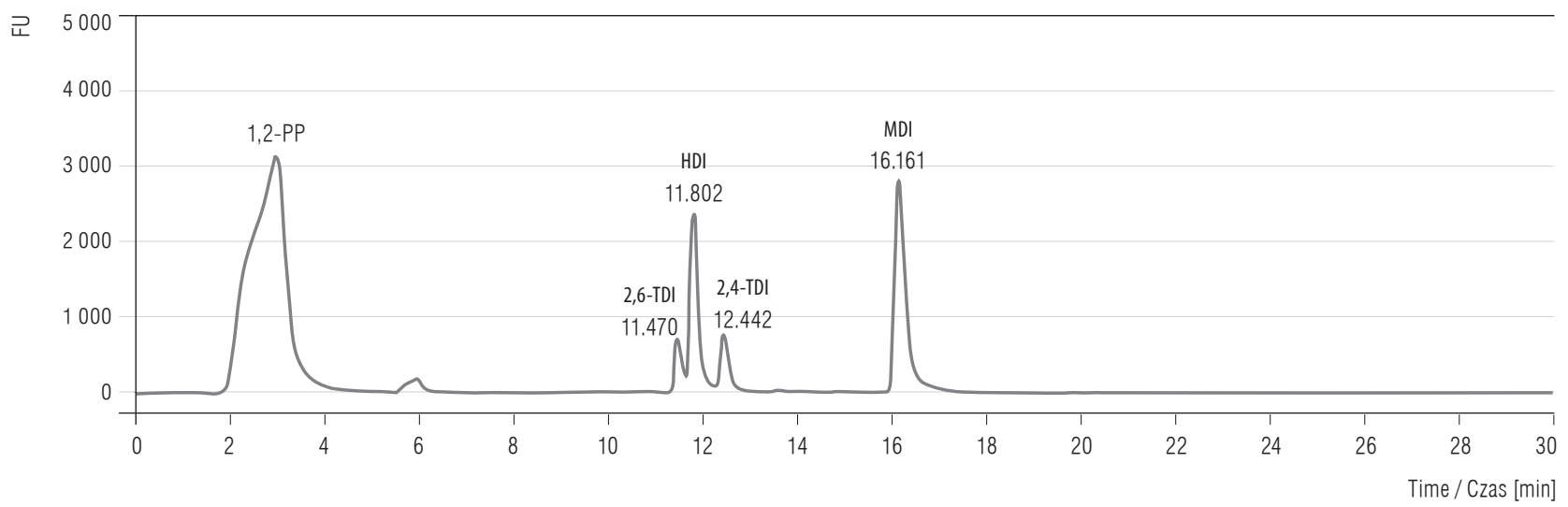

b)

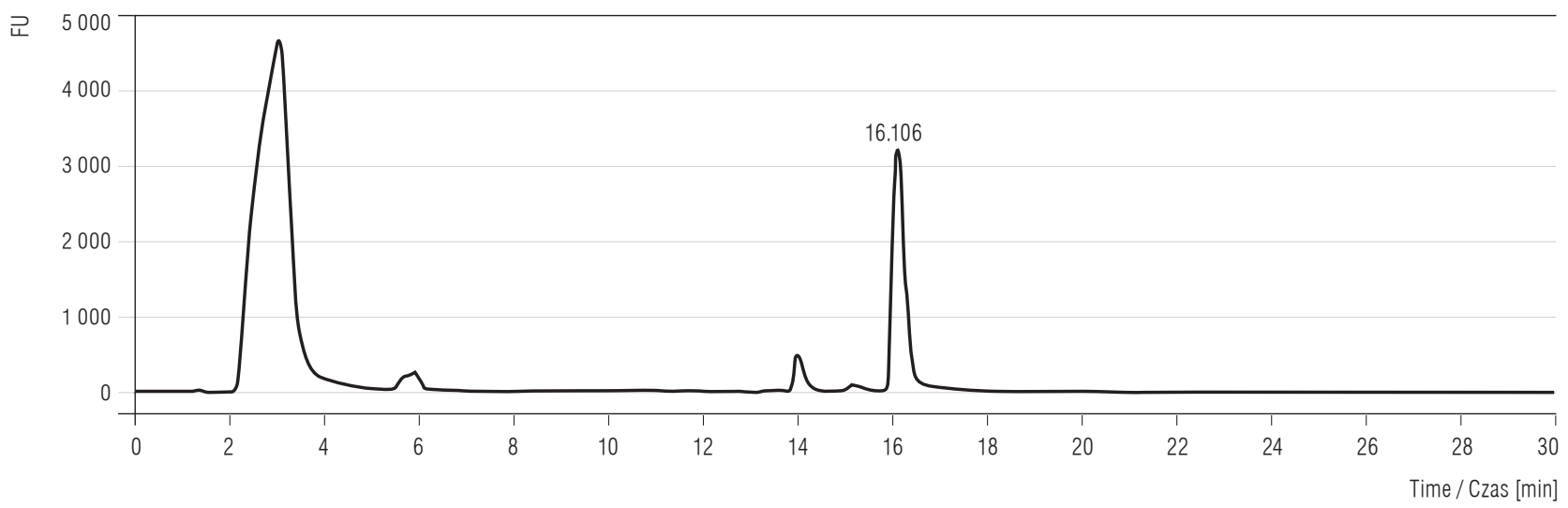

Izo-mix-wz-6; vial: 8; inj \#: 1; channel: 2475ChA ex260/em370

Wf-5-I; vial: 55; inj \#: 1; channel: 2475ChA ex260/em370

FU - fluorescence units / jednostki fluorescencji.

Other abbreviations as in the Tables 1 and 2 / Inne skróty jak w tabeli 1 i 2.

Fig. 1. Chromatogram of: a) diisocyanates derivatives standards, b) 1 of the analysed samples

Ryc. 1. Chromatogram: a) wzorców pochodnych diizocyjanianów, b) $1 \mathrm{z}$ analizowanych próbek 


\section{RESULTS}

Results of surveys are presented in Table 5. The largest group of plants was the one using MDI in manufacturing. For a total of 91 workplaces, in as much as 69 cases $(76 \%)$, the assayed concentrations of MDI were below the limit of quantitation (LOQ) of the analytical method used $\left(0.6 \mu \mathrm{g} / \mathrm{m}^{3}\right)$ or (the Plant O) MDI was not detected in any of the analyzed air samples. The highest concentrations of MDI were observed in the Plant I during application of polyurethane foam as an insulation for household appliances. The assayed concentrations of MDI during this task were between $11.5-18 \mu \mathrm{g} / \mathrm{m}^{3}$, which corresponded to about $1 / 3$ of the former MAC value. Surveys made at the same plant 2 years later show a 15-fold reduction of MDI concentrations in the working atmosphere.

Elevated concentrations of MDI (above $1 / 2$ of the current MAC value) were also registered in the Plant $\mathrm{R}$, where different products like netting, conveyor belt rollers, mixer parts, and polyurethane cladding for large parts (rollers, pipelines) were manufactured

Table 5. Concentration (TWA) of selected isocyanates in air samples collected during different industrial processes Tabela 5. Stężenie (średnie ważone) wybranych izocyjanianów w próbkach powietrza pobranych podczas różnych procesów przemysłowych

\begin{tabular}{|c|c|c|c|c|}
\hline \multirow[t]{2}{*}{$\begin{array}{c}\text { Plant } \\
\text { Zakład } \\
(\mathrm{N}=21)\end{array}$} & \multirow[t]{2}{*}{$\begin{array}{c}\text { Employees } \\
\text { Pracownicy } \\
(\mathrm{N}=129) \\
{[\mathrm{n}]}\end{array}$} & \multicolumn{3}{|c|}{$\begin{array}{c}\text { Concentration } \\
\text { (range }(\mathrm{Me})) \\
\text { Stężenie } \\
(\text { zakres }(\mathrm{Me})) \\
{\left[\mu \mathrm{g} / \mathrm{m}^{3}\right]}\end{array}$} \\
\hline & & MDI & HDI & $\mathrm{TDI}^{\mathrm{b}}$ \\
\hline A & 2 & $0.9-1.2(1.0)$ & & \\
\hline B & 2 & $0.9-2.7(1.8)$ & & \\
\hline $\mathrm{C}$ & 4 & $<0.6-5.2(3.5)$ & & \\
\hline $\mathrm{D}$ & 3 & & $6.0-8.0(7.0)$ & \\
\hline E & 10 & $<0.6$ & & \\
\hline $\mathrm{F}$ & 6 & $<0.6$ & & $7.0-12.7(9.8)$ \\
\hline G & 1 & $<0.6$ & & \\
\hline \multirow[t]{2}{*}{$\mathrm{H}^{\mathrm{a}}$} & 2 & & $<0.8-1.0(0.7)$ & \\
\hline & 1 & & $<0.8$ & \\
\hline \multirow[t]{2}{*}{$\mathrm{I}^{\mathrm{a}}$} & 2 & $11.5-18.0(15.0)$ & & \\
\hline & 3 & $<0.6-1.2(0.7)$ & & \\
\hline \multirow[t]{2}{*}{$\mathrm{J}^{\mathrm{a}}$} & 3 & & $<0.8-0.8(0.8)$ & \\
\hline & 3 & & $<0.8$ & \\
\hline K & 2 & $<0.6$ & & \\
\hline $\mathrm{L}$ & 2 & $<0.6-0.7(0.4)$ & & \\
\hline M & 2 & & $<0.8$ & \\
\hline $\mathrm{N}$ & 20 & $<0.6$ & & $0.2-58.8(4.0)$ \\
\hline $\mathrm{O}$ & 16 & n.d. & & \\
\hline $\mathrm{P}$ & 8 & $<0.6$ & & \\
\hline $\mathrm{R}$ & 12 & $<0.6-17.4(3.4)$ & & \\
\hline S & 6 & & & $1.9-12.6(5.3)$ \\
\hline $\mathrm{T}$ & 11 & $<0.6-3.3(0.8)$ & & \\
\hline $\mathrm{U}$ & 4 & $<0.6$ & & \\
\hline W & 4 & $<0.6$ & & \\
\hline
\end{tabular}

TWA - 8-hour time-weighted average / średnia ważona w przeliczeniu na 8-godzinny okres odniesienia.

${ }^{\text {a }}$ Plants surveyed twice / Zakłady objęte badaniami 2-krotnie.

b Sum of concentrations of 2,4-TDI and 2,6-TDI isomers / Suma stężeń izomerów 2,4-TDI i 2,6-TDI.

$\mathrm{Me}$ - median / mediana, n.d. - not detected / nie wykryto.

Other abbreviations as in the Tables 1 and 2 / Inne skróty jak w tabeli 1 i 2 . 
by molding or spraying. Data on MDI concentrations at various workplaces of this plant is presented in the Table 6. The highest exposure is related to the spraying task. Concentration of MDI measured during spraying amounted to $17.4 \mathrm{mg} / \mathrm{m}^{3}$ and exceeded $1 / 2$ of MAC value. The median value of MDI concentration calculated for sprayer and sprayer helpers stood at $7 \mu \mathrm{g} / \mathrm{m}^{3}$ (about $1 / 4 \mathrm{MAC}$ ). Concentrations of MDI measured during molding were 10 times lower and did not exceed 1/50 of Polish MAC value.

Determinations of HDI concentrations were conducted in the following plants: the plant manufacturing heating elements (the Plant D - painting with HDI based paints), the plant manufacturing components of automobile interiors (the Plant $\mathrm{H}$ - gluing and laminating) and the plant manufacturing light bulbs (the
Plant J - gluing of bulb elements). Only in the Plant D, where heating elements were painted using screen printing method, did HDI concentration approximate $1 / 5$ of the current MAC value $\left(40 \mu \mathrm{g} / \mathrm{m}^{3}\right)$. In the remaining cases the concentrations of this compound were low and did not exceed $1 \mu \mathrm{g} / \mathrm{m}^{3}$.

Taking into account identical MAC values and similar toxic properties of 2,4-TDI and 2,6-TDI, the results for TDI are specified as the sums of concentrations of both isomers. The highest concentrations of this compound were found in plants manufacturing polyurethane blocks using the continuous process (the Plant F, $\mathrm{N}$ and S). In the case of the Plant $\mathrm{F}$, the air samples were collected by another laboratory and sent to the NIOM for analysis purposes. To our best knowledge, the data for the Plants F and N refers to the same plant, but we have

Table 6. Concentration of MDI (TWA) in the course of manufacturing parts for agriculture machinery (the Plant R)

Tabela 6. Stężenie MDI (średnie ważone) podczas produkcji części maszyn rolniczych (Zakład R)

\begin{tabular}{|c|c|c|c|c|}
\hline $\begin{array}{c}\text { Task } \\
\text { Czynność }\end{array}$ & $\begin{array}{c}\text { Workers } \\
\text { Pracownicy } \\
(\mathrm{N}=129) \\
{[\mathrm{n}]}\end{array}$ & \multicolumn{3}{|c|}{$\begin{array}{c}\text { MDI concentration } \\
\text { Stężenie MDI } \\
{\left[\mu \mathrm{g} / \mathrm{m}^{3}\right]}\end{array}$} \\
\hline Molding / Odlewanie form & 6 & $<0.6-1.6$ & 0.9 & 0.7 \\
\hline Spraying - auxiliary works / Natryskiwanie - prace pomocnicze & 4 & $<0.6-7.3$ & 4.8 & 5.8 \\
\hline Laboratory tests / Testy laboratoryjne & 1 & $<0.6$ & - & - \\
\hline
\end{tabular}

M - mean / średnia.

Other abbreviations as in the Tables 1 and 5 / Inne skróty jak w tabeli 1 i 5.

Table 7. Concentration of TDI (TWA) in the course of manufacturing flexible polyurethane foam blocks Tabela 7. Stężenie TDI (średnie ważone) podczas produkcji bloków pianki poliuretanowej

\begin{tabular}{|c|c|c|c|c|c|c|}
\hline \multirow{3}{*}{$\begin{array}{c}\text { Workplace } \\
\text { (task) } \\
\text { Stanowisko pracy } \\
\text { (czynność) }\end{array}$} & \multicolumn{3}{|c|}{$\begin{array}{c}\text { Plant N } \\
\text { Zakład N }\end{array}$} & \multicolumn{3}{|c|}{$\begin{array}{c}\text { Plant S } \\
\text { Zakład S }\end{array}$} \\
\hline & \multirow[t]{2}{*}{$\begin{array}{c}\text { workers } \\
\text { pracownicy } \\
(\mathrm{N}=129) \\
{[\mathrm{n}]}\end{array}$} & \multicolumn{2}{|c|}{$\begin{array}{c}\text { sum of concentrations } \\
\text { of 2,4-TDI and 2,6-TDI } \\
\text { suma stężeń izomerów } \\
\text { 2,4-TDI i 2,6-TDI } \\
{\left[\mu \mathrm{g} / \mathrm{m}^{3}\right]}\end{array}$} & \multirow{2}{*}{$\begin{array}{c}\text { workers } \\
\text { pracownicy } \\
(\mathrm{N}=129) \\
{[\mathrm{n}]}\end{array}$} & \multicolumn{2}{|c|}{$\begin{array}{c}\text { sum of concentrations } \\
\text { of 2,4-TDI and 2,6-TDI } \\
\text { suma stężeń izomerów } \\
\text { 2,4-TDI i 2,6-TDI } \\
{\left[\mu \mathrm{g} / \mathrm{m}^{3}\right]}\end{array}$} \\
\hline & & $\begin{array}{l}\text { range } \\
\text { zakres }\end{array}$ & $\mathrm{M}(\mathrm{Me})$ & & $\begin{array}{l}\text { range } \\
\text { zakres }\end{array}$ & $\mathrm{M}(\mathrm{Me})$ \\
\hline Foaming head operator / Operator głowicy spieniającej & 10 & $0.6-11.3$ & $3.7(1.8)$ & 3 & $1.9-7.3$ & $3.8(2.2)$ \\
\hline Cutting machine operator / Operator przecinarki & 3 & $0.2-6.5$ & $3.6(4.5)$ & 2 & $3.1-4.7$ & $3.9(3.9)$ \\
\hline Maintenance tasks / Prace konserwacyjno-naprawcze & 2 & $9.9-41.5$ & $25.7(25.7)$ & - & - & - \\
\hline Folding paper / Zwijanie papieru & 5 & $0.3-58.7$ & $26.3(17.0)$ & 1 & - & 12.6 \\
\hline
\end{tabular}

Abbreviations as in the Tables 1, 5 and 6 / Skróty jak w tabelach 1, 5 i 6 . 
not received any information about tasks performed by workers in the Plant F. Thus, results for the Plants F an $\mathrm{N}$ are specified in the table as the data collected in 2 different plants. Concentrations of TDI registered in the Plant $\mathrm{N}$ in 8 cases $(\mathrm{N}=20)$ exceeded the cumulative exposure index (CEI) for TDI. In the Plant $\mathrm{S}$, the CEI value was exceeded in 2 cases $(\mathrm{N}=6)$.

At the remaining workplaces of both plants (a foaming head operator, cutting machine operator) the concentrations registered were lower and the values fluctuated around 1/2 MAC value. The data related to the results of measurements made in both plants is presented in the Table 7.

\section{DISCUSSION}

The presented results constitute the first quantified data on the occupational exposure to isocyanates in Poland. They show that, in general, the concentrations of the studied isocyanates are within the range of the values of respective hygienic standards currently valid in Poland.

The data presented in the Table 5 is similar to the data presented in the literature. In a study published in 2009, Booth et al. [15] presented results of a 16-year (1984-1999) study on concentrations of MDI assayed during various activities connected with the application of this chemical. For a total of 8134 measurements (4551 stationary and 3583 individual) in almost $75 \%$ of the cases the concentrations of MDI were below the detection limit of the analytical method used [15]. Kääriä et al. [16] registered similarly low concentrations of MDI in the workplace environment of 3 Finnish factories manufacturing refrigerators and freezers. For a total number of 205 personal air samples, in 131 cases (64\%) MDI concentrations were below the LOQ $\left(0.03 \mu \mathrm{g} / \mathrm{m}^{3}\right)$ of the employed analytical method. The highest measured concentration of MDI was $3.3 \mu \mathrm{g} / \mathrm{m}^{3}$, i.e., $3 \%$ of the Finnish occupational exposure limit (OEL). Our results, for the similar technological process (insulation of household appliances with rigid polyurethane foam - the Plant G and Plant I) are close to the results quoted above. The results obtained in 2007 in the Plant I, where the mean concentration of MDI was $15 \mu \mathrm{g} / \mathrm{m}^{3}$ (about $1 / 3$ of the MAC value valid in 2007) served the single exception. After improvements made in this plant (more efficient ventilation, better organization of work), concentrations of MDI dropped to the mean value of $0.7 \mu \mathrm{g} / \mathrm{m}^{3}$.

For the spraying process (insulation of buildings), Crespo and Galán [17] reported (for the sprayers)
MDI concentrations of 77 and $400 \mu \mathrm{g} / \mathrm{m}^{3}$ for outdoor and indoor operations, respectively. The levels of exposure measured for helpers were lower, but were still as high as $45 \mu \mathrm{g} / \mathrm{m}^{3}$ and $308 \mu \mathrm{g} / \mathrm{m}^{3}$ for outdoor and indoor operations, respectively. For a similar technological process (spraying of polyurethane cladding - the Plant R) but of course incomparably lower volume of production output, concentration of MDI was $17.4 \mu \mathrm{g} / \mathrm{m}^{3}$ (sprayer) and $4.8 \mu \mathrm{g} / \mathrm{m}^{3}$ (helpers: $\mathrm{N}=4$ ). Those values refer to $8 \mathrm{~h}$ work shift. Concentrations of MDI measured during the 1 st $4 \mathrm{~h}$ of work (including spraying operation) were much higher, $37 \mu \mathrm{g} / \mathrm{m}^{3}$ (sprayer) and $15.3 \mu \mathrm{g} / \mathrm{m}^{3}$ (helpers). During the 2nd part of the work shift, when workers were performing other tasks, MDI concentrations did not exceeded the LOQ value $\left(0.6 \mu \mathrm{g} / \mathrm{m}^{3}\right)$.

In Great Britain, Creely et al. [18] studied 21 plants, at which isocyanates (MDI, TDI, HDI, isophorone diisocyanate (IPDI)) were being used. For a total of 70 air samples, in 50 samples the concentrations of isocyanates (expressed as the NCO group) were lower than the LOQ of the analytical method used $\left(1 \mu \mathrm{g} / \mathrm{m}^{3}\right)$, and in only 3 of the cases (spray painters), concentrations of TDI exce-eded the OEL value $\left(20 \mu \mathrm{g} / \mathrm{m}^{3}\right)$. In studies conducted by Sennbro et al. [19] in 13 Swedish manufacturing plants, high concentrations of TDI were detected in the course of manufacturing polyurethane foam blocks (2 plants). Average levels of TDI (total of 2,4-TDI and 2,6-TDI) in the 1st plant $(\mathrm{N}=6)$ were $7.3 \mu \mathrm{g} / \mathrm{m}^{3}$ and in the 2 nd plant $(\mathrm{N}=4)-29.1 \mu \mathrm{g} / \mathrm{m}^{3}$, and were close to the results obtained for the same manufacturing process in our study (the Plant F, Plant N and Plant S).

Elevated concentrations of TDI determined for manufacturing of polyurethane foam blocks as well as MDI concentrations measured during spraying of polyurethane cladding are typical for the described manufacturing processes and performed tasks. Such results should be however assessed with great caution since the respiratory protection equipment (RPE) was used at some workplaces to minimize the exposure. The evaluation of role and influence of the RPE used by workers constitutes a separate problem. The Polish standard on the principles of air sample collection [20] requires from the person making measurements to document the presence of the RPE worn by workers, but the principles listed in the standard do not specify how it should be interpreted.

Isocyanates are considered as one of the main chemical compounds responsible for the development of occupational asthma. In a study published in 2012, 
Baur et al. [21] reviewed accessible literature concerning the incidence of irritating compounds responsible for the development of occupational asthma in work environments, as well as factors favoring the development of this disease. In 474 papers, authors detailed 188 factors (chemical compounds, professions, activities) causally associated with the development of occupational asthma. Out of this number, the strongest connection with this disease was attributed to 17 factors, including isocyanates.

The mechanism of generation of occupational asthma has not been completely explained. Many studies [22-24] indicate the possibility that occupational asthma may result from the prolonged exposure to low concentrations of isocyanates. Skin adsorption of isocyanates also seems to play an important role in the process of development of the changes in the respiratory system. Arrandale et al. [25] studied the relationship between changes appearing on skin and changes in airways of painters using lacquers containing isocyanates (HDI) and among bakers exposed to flour dust. For lacquer painters employed in automobile repair workshops, the authors established strong and statistically significant relationships between skin changes and pulmonary symptoms. Results of other studies also indicate the possibility of a relationship between allergic changes and the development of pathological symptoms (including occupational asthma) in lungs and airways [26-28]. This means that even in the case of proven low levels of isocyanates in work environments, one cannot exclude the possibility of the development of pulmonary diseases.

The estimation of the occupational dermal exposure to isocyanates is difficult and the results are likely to be imprecise. The method of biological monitoring based on the measurement of selected metabolites of these compounds in urine seems to be in this instance a significantly better and more adequate method for the assay of the occupational exposure to isocyanates independent of the absorption route.

The results of many scientific studies show that in spite of low levels of isocyanates in the ambient air, concentrations of their metabolites in biological material (urine, blood) samples collected from workers were several times higher than the concentrations of the compounds in the control groups. Kääriä et al. [16] found that despite the low levels of MDI in workplace atmosphere (64\% of cases below the LOQ) the urinary concentrations of MDI metabolite (4,4'-methylenedianiline - MDA) above the LOQ were detected in $94 \%$ of the collected samples. The same authors conducted similar studies on the exposure to TDI isomers. Although the measured TDI levels in the air were significantly higher than in the case of MDI, in the group of persons exposed to low levels of TDI (below LOQ), they also confirmed elevated levels of the metabolites of this compound in urine [29]. In studies conducted in 21 companies in Great Britain, Creely et al. [18] found that only in $4 \%$ of collected air samples the concentration of the determined compound exceeded the OEL value, while levels of its metabolites in urine exceeded the British Biological Monitoring Guidance Value (BMGV - $1 \mathrm{mmol} / \mathrm{mol}$ of creatinine) in 23 cases (33\%) [5].

\section{CONCLUSIONS}

The presented data is the 1st attempt in Poland to evaluate the occupational exposure to isocyanates during various industrial processes. We are aware that this data is incomplete - in some cases - because of the small size of the groups of workers and because of the inability (chiefly because of refusals to participate) to conduct studies during all processes associated with the use of isocyanates. We are also aware that some of results should be viewed with caution, namely in the instances of use of the respiratory protective equipment. On the other hand, low levels of isocyanates (particularly of low volatility MDI) in the air, cannot exclude the possibility of additional absorption of these compounds through skin.

Taking into consideration all the uncertainties associated with the evaluation of the risk of exposure to isocyanates based solely on measurement of their levels in the air, it would seem that only the simultaneous application of both forms of monitoring (environmental and biological) would facilitate a reliable assessment of the occupational exposure risk. The continuation of such a study would seem necessary in order to attempt to define uniform reference values for biological monitoring of isocyanates.

\section{REFERENCES}

1. Pałczyński C. [Asthma caused by low molecular weight agents]. In: Pałczyński C, editor. [Allergenic agents in the work environment]. Warszawa: Centrum Medyczne Kształcenia Podyplomowego; 2011. p. 73-83. Polish.

2. International Agency for Research on Cancer. Monographs on the evaluation of the carcinogenic risk of chemicals to man. Re-evaluation of some organic chemicals, 
hydrazine and hydrogen peroxide. Toluene diisocyanates. Geneva: IARC; 1999;71(Pt2):865.

3. [Ordinance of the Minister of Labour and Social Policy of 16 June 2009 amending the regulation on maximum permissible concentrations and intensities of harmful factors in the work environment. J Law 2009, No. 105, item 873]. Polish.

4. American Conference of Governmental Industrial Hygienists. Threshold limit values for chemical substances and physical agents. Biological exposure indices. ACGIH: Cincinnati; 2013.

5. Health and Safety Executive. Watch Committee. Biological monitoring for isocyanates. October 2005 [cited 2014 Apr 29]. Avaliable from: http://www.hse.gov.uk/aboutus/ meetings/iacs/acts/watch/051005/13.pdf.

6. European Commission, Council of the European Union. Regulation (EC) No. 1907/2006 of the European Parliament and of the Council of 18 December 2006 concerning the Registration, Evaluation, Authorisation and Restriction of Chemicals (REACH), establishing a European Chemicals Agency, amending Directive 1999/45/EC and repealing Council Regulation (EEC) No. 793/93 and Commission Regulation (EC) No. 1488/94 as well as Council Directive 76/769/EEC and Commission Directives 91/155/ EEC, 93/67/EEC, 93/105/EC and 2000/21/EC. Off J Eur Union, L 396. p. 1-394.

7. Marquart H, Northage C, Money C. Exposure scenarios for workers. J Expo Sci Environ Epidemiol. 2007;17 Suppl 1:S16-25, http://dx.doi.org/10.1038/sj.jes.7500617.

8. Schaafsma G, Kroese ED, Tielemans ELJP, van de Sandt JJM, van Leeuwen CJ. REACH, non-testing approaches and the urgent need for a change in mind set. Regul Toxicol Pharmacol. 2009;53(1):70-80, http:// dx.doi.org/10.1016/j.yrtph.2008.11.003.

9. Money CD, Jacobi S, Penman MG, Rodriguez C, de Rooij C, Veenstra G. The ECETOC approach to targeted risk assessment; Lessons and experiences relevant to REACH. J Expo Sci Environ Epidemiol. 2007;17:S67-71, http://dx.doi.org/10.1038/sj.jes.7500565.

10. Vink SR, Mikkers J, Bouwman T, Marquart H, Kroese ED. Use of read-across and tiered exposure assessment in risk assessment under REACH - A case study on a phase-in substance. Regul Toxicol Pharmacol. 2010;58(1): 64-71, http://dx.doi.org/10.1016/j.yrtph.2010.04.004.

11. Kupczewska-Dobecka M, Czerczak S, Brzeźnicki S. Assessment of exposure to TDI and MDI during polyurethane foam production in Poland using integrated theoretical and experimental data. Environ Toxicol Pharmacol. 2012;34(2):512-8, http://dx.doi.org/10.1016/ j.etap.2012.06.006.
12. Occupational Safety and Health Administration. Sampling and analytical methods. Organic method \#42. Diisocyanates [cited 2014 Apr 29]. Avaliable from: https://www. osha.gov/dts/sltc/methods/organic/org042/org042.html.

13. Occupational Safety and Health Administration. Sampling and analytical methods. Organic method \#47. Methylene bisphenyl isocyanate (MDI) [cited 2014 Apr 29]. Avaliable from: https://www.osha.gov/dts/sltc/methods/ organic/org047/org047.html.

14. Health and Safety Executive. Methods for the determination of hazardous substances (MDHS). MDHS guidance 3-25/3. MDHS25/3: Organic isocyanates in air [cited 2014 Apr 29]. Available from: http://www.hse.gov.uk/ pubns/mdhs/pdfs/mdhs25-3.pdf.

15. Booth K, Cummings B, Karoly WJ, Mullins S, Robert WP, Spence M, et al. Measurements of airborne methylene diphenyl diisocyanate (MDI) concentration in U.S. workplace. J Occup Environ Hyg. 2009;6(4):228-38, http:// dx.doi.org/10.1080/15459620902724060.

16. Kääriä K, Hirvonen A, Norppa H, Piirilä P, Vainioa K, Rosenberg C. Exposure to 4,4'-methylenediphenyl diisocyanate (MDI) during moulding of rigid polyurethane foam: Determination of airborne MDI and urinary 4,4'-methylenedianiline (MDA). Analyst 2001; 126(4):476-9, http://dx.doi.org/10.1039/B009549O.

17. Crespo J, Galán J. Exposure to MDI during the process of insulating buildings with sprayed polyurethane foam. Ann Occup Hyg. 1999;43(6):415-9, http://dx.doi. org/10.1093/annhyg/43.6.415.

18. Creely KS, Hughson GW, Cocker J, Jones K. Assessing isocyanate exposures in polyurethane industry sectors using biological and air monitoring methods. Ann Occup Hyg. 2006;50(6):609-21, http://dx.doi.org/10.1093/ annhyg/mel024.

19. Sennbro CJ, Lindh $\mathrm{CH}$, Ōstin A, Welinder H, Jönsson BAG, Tinnerberg H. A survey of airborne isocyanate exposure in 13 Swedish polyurethane industries. Ann Occup Hyg. 2004;48(5):405-14, http://dx.doi. org/10.1093/annhyg/meh034.

20. PN-Z-04008-7:2002/Az1:2004. [Air purity protection. Sampling methods. Principles of air sampling in work environment and interpretation of results]. Warszawa: Polski Komitet Normalizacyjny; 2004. Polish.

21. Baur X, Bakehe $P$, Vellguth $H$. Bronchial asthma and COPD due to irritants in the workplace - An evidence-based approach. J Occup Med Toxicol. 2012;7:19, http://dx.doi.org/10.1186/1745-6673-7-19.

22. Fishwick D. New occupational and environmental causes of asthma and extrinsic allergic alveolitis. Clin Chest Med. 2012; 33(4):605-16, http://dx.doi.org/10.1016/j.ccm.2012.07.002. 
23. Suojalehto H, Linström I, Henriks-Eckerman M-L, Jungewelter S, Suuronen K. Occupational asthma related to low levels of airborne methylene diphenyl diisocyanate (MDI) in orthopedic casting work. Am J Ind Med. 2011;54(12):906-10, http://dx.doi.org/10.1002/ajim.21010.

24. Campo P, Aranda A, Rondon C, Doña I, Díaz-Perales A, Canto $\mathrm{G}$, et al. Work-related sensitization and respiratory symptoms in carpentry apprentices exposed to wood dust and diisocyanates. Ann Allergy Asthma Immunol. 2010; 105(1):24-30, http://dx.doi.org/10.1016/j.anai.2010.05.002.

25. Arrandale V, Meijster T, Pronk A, Doekes G, Redlich CA, Holness DL, et al. Skin symptoms in bakery and auto body shop workers: Associations with exposure and respiratory symptoms. Int Arch Occup Environ Health. 2013;86(2):167-75, http://dx.doi.org/10.1007/s00420-0120760-x.

26. Petsonk EL. Work-related asthma and implications for the general public. Environ Health Perspect. 2002;110 Suppl 4:569-72.
27. Donnelly R, Buick JB, Macmahon J. Occupational asthma after exposure to plaster casts containing methylene diphenyl diisocyanate. Occup Med. 2004;54(6):432-4, http://dx.doi.org/10.1093/occmed/kqg133.

28. Wisnewski AV, Xu L, Robinson E, Liu J, Redlich CA, Herrick CA. Immune sensitization to methylene diphenyl diisocyanate (MDI) resulting from skin exposure: Albumin as a carrier protein connecting skin exposure to subsequent respiratory responses. J Occup Med Toxicol. 2011;6:6, http://dx.doi.org/10.1186/1745-6673-6-6.

29. Kääriä K, Hirvonen A, Norppa H, Piirilä P, Vainio A, Rosenberg C. Exposure to 2,4- and 2,6-toluene diisocyanate (TDI) during production of flexible foam: Determination of airborne TDI and urinary 2,4- and 2,6-toluenediamine (TDA). Analyst. 2001;126(7):1025-31, http:// dx.doi.org/10.1039/B102022F.

The use of the article "Occupational exposure to selected isocyanates in Polish industry" is available in Open Access model and permitted under license conditions of Creative Commons Attribution-NonCommercial 3.0 (also known as CC-BY-NC), available at http://creativecommons.org/licenses/ by-nc/3.0/pl/deed.en or another language version of this license or any later version of this license published by Creative Commons / Zezwala się na korzystanie z artykułu „Zawodowe narażenie na wybrane izocyjaniany w polskim przemyśle” w modelu open access na warunkach licencji Creative Commons Uznanie autorstwa - Użycie niekomercyjne 3.0 (znanej również jako CC-BY-NC), dostępnej pod adresem http://creativecommons.org/licenses/ by-nc/3.0/pl/ lub innej wersji językowej tej licencji lub którejkolwiek późniejszej wersji tej licencji, opublikowanej przez organizację Creative Commons. 